their presence in effective concentrations, or even genetically engineering their presence in fruits and vegetables that do not contain them may be effective methods of reducing pectolytic enzyme activity and increasing resistance.

Calcium has been more closely related to disease resistance than any other cation associated with the cell wall. Calcium's role in forming cation cross bridges between pectic acids or between pectic acids and other polysaccharides with acid groups may make the cell wall less accessible to enzymes produced by fungal pathogens that cause decay (Tepfer and Taylor, 1981). In bean (Phaseolus vulgaris L.) tissue infected with Rhizoctonia solani Kuhn, tissue maceration by polygalacturonase was reduced as $\mathrm{Ca}$ content increased (Bateman, 1964). Increasing the $\mathrm{Ca}$ content of fruits and vegetables may be a way to decrease postharvest decay while reducing pesticide use.

Anew strategy that shows promise in controlling pathogens during storage is the management of microflora on the surface of fruits and vegetables to enhance resistance to postharvest pathogens (Wilson, 1989). The beneficial microflora are considered antagonists to pathogens that cause storage losses and, therefore, act as biological control agents. The mode of action of various biological control agents is being studied, as well as the optimum methods by which these agents can be incorporated into control strategies in the postharvest and storage environments.

The goal of this colloquium, through the papers that follow, is to consider various types of infections and mechanisms involved with postharvest diseases and to discuss recent advances in postharvest disease control strategies. Reducing postharvest losses will not only benefit the U.S. food supply, but also that of developing countries where there are continually increasing demands for food by growing populations.

\section{Literature Cited}

Abu-goukh, A.A. and J.M. Labavitch. 1983. The in vivo role of 'Bartlett' pear fruit polygalacturonase inhibitors. Physiol. Plant Pathol. 23:123-135.

Bateman, D.F. 1964. An induced mechanism of tissue resistance to polygalacturonase in Rhizoctonia -infected hypocotyls of bean. Phytopathology 54:438-445.

Bateman, D.F. and H.G. Basham. 1976. Degradation of plant cell walls and membranes by microbial enzymes; p. 316-355. In: R. Heitefuss and P.H. Williams (eds.). Encyclopedia of plant physiology. vol. 4. SpringerVerlag, New York

Booth, R.H. 1974. Post-harvest deterioration of tropical root crops: Losses and their control. Trop. Sci. 16:49-63.

Brown, A.E, and N.K.B. Adikaram. 1982. The differential inhibition of pectic enzymes from Glomerella cingulata and Botrytis cinerea by cell wall protein from Capsicum апnиum fruit. Phytopathol. Z. 105:27-38.

Coursey, D.G. 1981. Traditional post-harvest technology of tropical perishable staples. Industry Environ. 4: 10-14.

Eckert, J.W. and M. Ratnake. 1983. Host pathogen interactions in postharvest diseases, 46:247-264. In: M. Lieberman (ed.). NATO Advanced Study Institute series. Plenum, New York.

El-Goorani, M.A. and N.F. Sommer. 1981. Effects of modified atmospheres on postharvest pathogens of fruits and vegetables. Hort. Rev. 3:412461.

Hulse, J.H. 1982. Food science and nutrition: The gulf between rich and poor. Science 216: 1291-1294.

Kader, A.A. 1985. Biochemical and physiological basis for effects of controlled and modified atmospheres on fruits and vegetables. Food Technol. 40:99-104.

National Academy of Sciences. 1978. Postharvest food losses in developing countries. National Academy of Sciences, Washington, D.C.

Tepfer, M. and I.E.P. Taylor. 1981. The interaction of divalent cations with pectic substances and their influence on acid induced cell wall loosening. Can. J. Bet. 59:1522-1525.

Wilson, C.L. 1989. Managing the microflora of harvested fruits and vegetables to enhance resistance. Phytopathology 79:1387-1390.

\title{
Mechanical Injury and Latent Infections Leading to Postharvest Decay
}

\author{
Benny D. Bruton ${ }^{1}$ \\ U.S. Department of Agriculture, Agricultural Research Service, Lane, OK 74555
}

Economic losses due to postharvest decays are higher than is often recognized. Because of the added costs of harvesting, packaging, transporting, and marketing, the value of fresh fruits and vegetables increases several-fold from the field to the consumer. These losses are accompanied by"' the nonproductive use of resources, such as land, fertilizer," pesticides, water, labor, and energy, during production. Pesticides are needed to produce and protect inexpensive fresh produce on a large scale. However, public concerns over food safety have become a major concern. Preharvest fungicide applications may have a beneficial carryover effect, i.e., in reducing postharvest decays. Postharvest fungicide applications are made routinely on many freshmarket fruits and vegetables. Consequently, fresh produce may contain fungicide residues within established Food and Drug Administration tolerances. In many cases, the cost of reducing postharvest diseases may be greater than the value of the fruits and vegetables at harvest. Farming operations that use integrated pest management, low-input agriculture, organic farming, and others will undoubtedly present us with new challenges in postharvest research. It becomes even more compelling that we as plant pathologists, horticulturists, and plant physiologists develop a cooperative team approach to undertake these challenges.

Research Plant Pathologist.

\section{INFECTIONS LEADING TO POSTHARVEST DISEASE}

Numerous factors influence postharvest quality and shelf life. The preharvest environment and production methods have a large impact on postharvest diseases. Produce grown under less than optimum conditions are more likely to be predisposed to postharvest diseases than those grown under optimum conditions. Proper storage temperature and humidity are probably the most important postharvest disease control measures available. Refrigeration and high humidity retard senescence and the growth of many postharvest pathogens.

Some fungal pathogens are capable of penetrating intact surfaces of fruits and vegetables, although most enter at a wound site. Bacteria gain entry only through wounds or natural openings, such as stomata and lenticels. Fungi are typically involved in postharvest decays of fruit (Dennis, 1983), whereas vegetables may be attacked by either fungi or bacteria (Bartz and Eckert, 1987; Lund, 1983). Infections leading to postharvest decay can be separated into three categories: 1) incipient infections, 2) wound infections, and 3) latent or quiescent infections.

Incipient infections occur at any time before or after harvest. Incipient infections may remain active, causing decay, although they are often arrested as a result of exogenous influences, i.e., fungicide application and refrigeration. By definition, incipient means just beginning to exist or to come to notice. Many incipient infection; on produce may pass through the culling process at any time during harvesting, packaging, or retail display. 
Latent infections occur during growth and development of the produce. A fungal spore may land on the immature fruit, germinate, and penetrate the cuticle and outer cell wall; establish a parasitic relationship with its host: and subsequently become dormant or quiescent. Further development of the fungus is arrested until the fruit has ripened (Swinburne, 1983; Verhoeff, 1974). Latent infections, as with incipient infections in produce, are impossible to quantify, and as a result, the incidence of decay for any particular shipment is unknown. The triggering mechanisms by which the pathogen again becomes active are largely unknown. Simmonds ( 1963) presented four possible explanations: 1) toxins are present in unripe, but not ripe, fruit; 2) the pathogen's nutritional requirements are not met because of the composition of unripe fruit; 3 ) the energy requirements of the fungus are met only after the host has ripened sufficiently; and 4) the enzyme potential of the fungus is insufficient to invade immature fruit. In most fruits and vegetables, several mechanisms are involved in transforming a dormant infection into an active one that results in decay.

Wound infections cause the most severe problem in postharvest decays. With increased emphasis on mechanized harvesting and bulk handling, wound infections are increasingly more prominent. Stemend injury created during harvesting is a common site of invasion by wound pathogens. There will always be a certain amount of wound injury, regardless of the harvesting operation. Injury caused by heat, low temperature, ethylene, and various other adversities presents essentially the same avenue for wound pathogens as an open wound.

\section{ENHANCING NATURAL MECHANISMS}

The nutritional condition of the plant can determine to a large extent the degree of disease resistance or susceptibility (Huber, 1991). The morphological and physiological properties of cells or tissues may be altered in such away as to retard or hasten decay. In general, $\mathrm{N}$ tends to increase susceptibility, while $\mathrm{Ca}$ and $\mathrm{K}$ tend to increase disease resistance; $\mathrm{P}$ may elicit either response. Manipulating host nutrition provides a useful tool to enhance other integrated control measures. Although volumes of literature exist on nutritional status and plant disease, information about the influence of nutrition on postharvest decays is seriously lacking. Cellular and membrane integrity play a major role in spore germination and fungal growth. Calcium has probably been studied in greater detail with respect to postharvest quality (Poovaiah, 1988) and disease (Conway et al., 1988, 1991) than any other element.

\section{TISSUE-MACERATING ENZYMES}

The plant cell wall is typically divided into three regions based on composition and design: the middle lamella, primary cell wall, and secondary cell wall. No clear boundary exists between the three regions and, in fact, the cell wall is somewhat of a continuum. The middle lamella, consisting primarily of pectic polysaccharides, cements cell walls together. Pathogen-produced pectolytic enzymes break down these pectic polymers, leading to loss of structural integrity and cell separation, a process known as maceration (Wood, 1967). Due to the accessibility of pectic polymers in the primary cell wall to enzymatic attack and the resulting release of pectic inducers, pectic enzymes are the first polysaccharides to be produced in tissue infected by fungi (Collmer and Keen, 1986). Postharvest diseases of fungal origin produce one or more of the following pectic enzymes: pectin esterase, endo- or exopolygalacturonase, endo- or exopectate lyase, and endopectin lyase (Dennis, 1987). The endopectin lyases are produced almost exclusively by fungi, while the endopectate lyases are produced primarily by bacteria (Chesson, 1980). Almost every pathogen-enzyme system interacts in a specific manner, depending on the plant tissue encountered. Plant pathogenic and nonpathogenic organisms are capable of producing a variety of cellwall-degrading enzymes. The mere fact that a fungus can produce cell-wall-degrading enzymes does not mean it will be a successful pathogen. There are many factors involved in host-pathogen interaction, ranging from illicitors to phytoalexins. Furthermore, extrapolation from in vitro enzyme studies to an in vivo process should proceed cautiously.

\section{CONTROL}

Control of postharvest decays is becoming more difficult than ever before as fungicides are taken off the market and public demands for residue-free, fresh produce increase. An integrated pest management approach has been used during crop production for years. A similar philosophy needs to be adopted by those of us working in postharvest research. Many microorganisms have developed resistance to commonly used chemicals, while no chemicals currently exist to control other pathogens. The success of chemical treatment depends on the type and extent of infection, sensitivity to the chemical, postharvest storage conditions, and numerous other factors (Eckert and Sommer, 1967). Hot water treatment has been beneficial, especially when used in conjunction with fungicides (Wells, 1971). The effects of both have been suggested to be additive or even synergistic. However, in some produce, the combination of hot water and fungicide has increased the fungicide residue concentration within the fruit (B. D. B., unpublished data). Care should be taken so that residue tolerances are not exceeded. Irradiation also has some benefits, but generally, fungal tolerance to ionizing radiation far exceeds that of the produce (Maxie et al., 1971). Modified or controlled atmosphere has shown some real promise in controlling some postharvest diseases (Kader, 1985). In addition, shrink-wrapping is being successfully employed for some produce (Ben-Yehoshua, 1985). Biological control of postharvest diseases is a fairly new concept that should play an important role in the management scheme; it has met with limited but promising success (Pusey, 1989). Genetic manipulation also offers some exciting possibilities for controlling postharvest diseases (Mount and Berman, 1994).

We have numerous tools available for developing postharvest disease control technology. Some of the old standbys are still viable and must be integrated with such techniques as biological control and genetic manipulation. Major advances have been made in the past 20 years in reducing postharvest diseases of fruits and vegetables. However, when one considers that postharvest losses may range as high as $10 \%$ to $30 \%$, it is alarming that we have few federal and state scientists working on postharvest diseases. The answer is not to produce more but to save more of what we produce. The scientific community, especially federal and state institutions, must form a partnership in the quest to develop the technology for postharvest disease control.

\section{Literature Cited}

Bartz, J.A. and J.W. Eckert. 1987. Bacterial disease of vegetable crops after harvest, p. 352-376. In: J. Weichman (ed.). Postharvest physiology of vegetables. Marcel Dekker, New York.

Ben-Yehoshua, S. 1985. Individual seal-packaging of fruit and vegetables in plastic film-A new postharvest technique. HortScience 20:32-37.

Chesson, A. 1980. Maceration in relation to the post-harvest handling and processing of plant material. J. Appl. Bactenol. 48:145.

Collmer, A. and N.T. Keen. 1986. The role of pectic enzymes in plant pathogenesis. Annu. Rev. Phytopathol. 24:383-409.

Conway, W. S., K.C. Gross, C.D. Boyer, and C.E. Sams. 1988. Inhibition of Penicillium expansum polygalacturonase activity by increased apple cell wall calcium. Phytopathology 78:1052-1055.

Conway, W. S., C.E. Sams, J.A. Abbott, and B.D, Bruton. 1991. Postharvest calcium treatment of apple fruit to provide broad-spectrum protection against postharvest pathogens. Plant Dis, 75:62\&622.

Dennis, C. 1983. Soft fruits, p, 23-42. In: C. Dennis (cd.). Post-harvest pathology of fruits and vegetables. Academic, New York.

Dennis, C. 1987, Fungi, p. 377411. In: J. Weichman (ed.). Postharvest physiology of vegetables. Marcel Dekker, New York.

Eckert, J.W. and N.F. Sommer, 1967. Control of diseases of fruits and vegetables by postharvest treatments. Annu. Rev. Phytopathol. 5:391-432.

Huber, D.M. 1991. The use of fertilizers and organic amendments in the control of plant disease, p. 405494. In: D. Pimentel (ed,). CRC handbook of pest management in agriculture. vol. I. 2nd ed. CRC Press, Boca Raton, Fla.

Kader, A.A. 1985. Modified atmospheres and low-pressure systems during transport and storage, p. 58-64. In: A.A. Kader (ed.). Postharvest technology of horticultural crops. Univ. of California Coop. Ext. Special Publ. 3311

Lund, B.M. 1983. Bacterial spoilage, p. 2 19-257. In: C. Dennis (ed.). Postharvest pathology of fruits and vegetables. Academic, New York.

Maxie, E.C., N.F. Sommer, and F.G. Mitchell. 1971. Infeasibility of irradiating fresh fruits and vegetables. HortScience 6:202-204. 
Mount, M.S. and P.M. Berman. 1994. Genetic manipulation of plants to improve postharvest disease resistance. HortScience 29:762-768.

Poovaiah, B.W., G.M. Glenn, and A.S.N. Reddy. 1988. Calcium and fruit softening: Physiology and biochemistry. Hort. Rev. 10:107-151.

Pusey, P.L. 1989. Use of Bacillus subtilis and related organisms as biofungicides. Pesticide Sci. 27:133-140.

Simmonds, J.H. 1963. Studies in the latent phase of Colletrotichum species concerning ripe rots of tropical fruits. Queensland J. Agr. Sci. 20:373-424

Swinburne, T.R. 1983. Quiescent infections in post-harvest diseases, p. 1-21.
In: C. Dennis (ed.). Post-harvest pathology of fruits and vegetables. Academic, New York.

Verhoeff, K. 1974. Latent infections by fungi. Annu. Rev. Phytopathol. 12:99110 .

Wells, J.M. 1971. Postharvest hot-water and fungicide treatments for reduction of decay of California peaches, plums, and nectarines. U.S. Dept. Agr. Market Res. Rpt. 980.

Wood, R.K.S. 1967. Physiological plant pathology. Blackwell Scientific, Oxford, England.

\title{
Latent Infections in the Pre- and Postharvest Environment
}

\author{
William R. Jarvis \\ Agriculture Canada, Research Station, Harrow, Ont. NOR I GO, Canada
}

For the epidemiologist, latency is the period from infection until the infected tissue becomes infectious, "spore-to-spore" (Vanderplank, 1963), but it generally has come to mean a period of pathogen quiescence (Verhoeff, 1974), sometimes even extended to cover the time when microorganisms lie quiescent on the host surface before infection occurs. In managing diseases of horticultural crops, pathogen quiescence has important implications in timing prophylaxis, the reduction of stresses that trigger the transition of quiescence to aggression, and managing the harvested crop to prolong quiescence to the point at which yield is no longer affected.

The inception of pathogen quiescence and its maintenance on or within the host implies a dynamic equilibrium between the host, the pathogen, and their environment. Physiological and physical changes in the host, its environment, or both trigger changes in that equilibrium to permit the pathogen to resume aggression. Microorganisms lying on the host surface constitute a potential latent infection; as can be the case with Botrytis cinerea Pers. :Fr. conidia that are prevented from germinating by antagonistic bacteria on leaf surfaces (Blakeman and Fokkema, 1982; Cline, 1985). Quiescence can run the spectrum from the ungerminated spore; through symptomless, internal infections; to visible but nonexpanding lesions, such as ghost spot of tomato (Lycopersicon esculentum Mill.) (Verhoeff, 1970); to expanding lesions on banana (Musa $\times$ paradisiaca $\mathrm{L}$.), caused by Colletotrichum musae (Berk. \& M.A. Curtis) Arx (Simmonds, 1941), and on avocado (Persea americana Mill.), caused by C. gloeosporioides (Penz.) Penz. $\&$ Sacc. (Binyamini and Schiffmann-Nadel, 1972). With the exception of tomato ghost spot, most quiescent infections eventually become aggressive rots in the field and, if undetected, in stored and marketed produce.

Quiescent infections are common in a wide variety of fruit, vegetable, and floral crops. They are caused by bacteria (Bartz, 1981; Hayward, 1974; Leben, 1981) and fungi (Baker et al., 1940; Jenkins and Reinganum, 1965; Rosenberger, 1983; Swinburne, 1983; Verhoeff, 1974). Soft rot bacteria are common in apparently healthy tomatoes (Bartz, 1981; Samish and Etinger-Tulczynska, 1963), cucumbers (Cucumis sativus L.) (Leben, 1981; Menelly and Stanghellini, 1975; Samish and Dimant, 1959), and potato (Solarium tuberosum L.) tubers (Perombelon and Kelman, 1988). Also in potatoes, quiescent Clavibacter michiganense subsp. sepedonicum (Spieck. \& Koth) Davis et al. is a serious impediment to export trade (de Boer and McNaughton, 1986). The world's three most important small-berry crops, grapes (Vitis vinifera L.) (McClellan and Hewitt, 1973; Pezet and Pent, 1986), strawberries (Fragaria $\times$ ananassa Duch.) (Jarvis, 1962; Powelson, 1960), and raspberries (Rubus idaeus L.) (Bristow et al., 1986; Jarvis, 1962; Powelson, 1960; Williamson et al., 1987), all have quiescent infections of Botrytis cinerea established in their floral parts; these infections usually become aggressive in ripe fruit. However, aggression may be significantly advanced in wet weather, when, for example, normally resistant green strawberries succumb to gray mold. Botrytis cinerea also can establish a quiescent infection in apple (Malus domestics Borkh.) calyx, which becomes eye rot (Tronsmo and Raa, 1977), and in fruit wounds (Lakshiminarayana et al., 1987).
Quiescent petal flecking in many floral crops is also frequently caused by B. cinerea (Cline, 1985) and other host-specific Botrytis spp. in the monocotyledonous Corolliferae and the Ranunculaceae (Jarvis, 1977). In the Sclerotiniaceae, Monilinia fructicola (G. Wint.) Honey is quiescent in stone fruits (Jenkins and Reinganum, 1965), and Sclerotinia sclerotiorum (Lib.) de Bary is quiescent in many vegetables (Smith et al., 1966), including carrots (Daucus carota L.) (Tahvonen, 1985). Botrytis aclada Fresen. is quiescent in onions (Allium cepa L.) (Tichelaar, 1967) and is responsible for neck rot in storage. Outside the Sclerotiniaceae, Colletotrichum spp. are common quiescent pathogens of tropical fruit (Baker et al., 1940; Binyamini and SchiffmannNadel, 1972; Simmonds, 1941).

\section{Mechanisms of quiescence}

In most unripe fruit and stem and root vegetables, the mechanisms limiting pathogen aggression are associated with either preformed antimicrobial substances (phytoncides) or with phytoalexins, enzymes, or physically resistant structures. A wide variety of postulates have been, or can be, advanced to explain quiescence (Dennis, 1983; Hayward, 1974; Verhoeff, 1974). Most of these postulate that aggression begins when certain physiological and physical changes occur, particularly in the host cell wall (Fisher and Bennett, 199 1; Hondelmann and Richter, 1973). The changes in dynamic equilibrium between climacteric metabolism and the strains induced by the stress of infection involve ethylene production (Takeda and Nakamura, 1990). Other stresses are imposed by such factors as wounding (Bruton, 1994), an unduly wet flowering season in strawberries, harvesting in potatoes, and inappropriate storage conditions.

\section{Implications of quiescence in disease control}

Setting aside the epiphytic populations of potential pathogens on plant surfaces, which may be controlled by pesticides (Fokkema and de Nooij, 1981) and biological agents (Blakeman and Fokkema, 1982; Wilson, 1989), the infection process, as defined by breaching the host epidermis, may occur several days or weeks before symptoms appear. This means that it is essential to know what environmental conditions permit infection to occur. In strawberries, white flower buds and fully open flowers are the most susceptible to infection, and the calyx and corolla are more susceptible than the receptacle (Jarvis and Borecka, 1968). Strawberries and raspberries present a difficult problem in timing prophylaxis because of the cymose inflorescences' long development sequence (Jarvis, 1969). This situation is further complicated by the finding that first-formed berries in the strawberry inflorescence are more susceptible to gray mold than successively later berries on the same inflorescence (Grainger, 1956). That microorganisms must be prevented from breaching the host epidermis means that the choice of pesticide is restricted to those that act on contact with the pathogen on the host surface; systemic, eradicant pesticides are less successful since they usually act imperfectly after infection. 